Section Editor

Mitchell S.V. Elkind,

MD, MS

Heather Rigby, MD

R. Mark Sadler, MD, FRCP $(\mathrm{C})$

Address correspondence and reprint requests to Dr. Heather Rigby, Division of Neurology, Halifax Infirmary, Dalhousie University, 1796 Summer St., Room 3383, Halifax, NS B3H3A7, Canada

hbmann@dal.ca

\title{
Teaching NeuroImages: \\ Postictal subconjunctival hemorrhages and skin petechiae
}

Figure Facial petechial rash and bilateral subconjunctival hemorrhages following a secondarily generalized tonic-clonic seizure

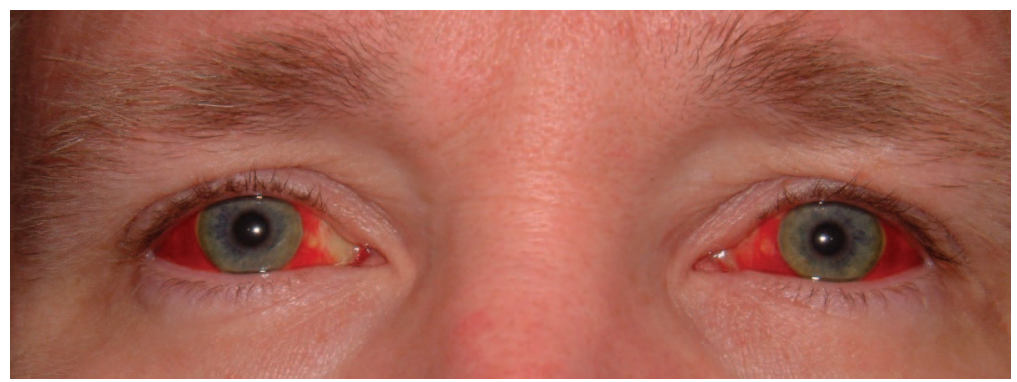

A 45-year-old man was evaluated for a seizure disorder of unknown cause characterized by secondarily generalized tonic-clonic seizures.

He reported bilateral subconjunctival hemorrhages and facial petechiae immediately following most of his seizures (figure). These physical findings were the only indications that a seizure had occurred when the ictus was in sleep.

Although petechial rash is described as a rare seizureinduced physical finding, ${ }^{1,2}$ subconjunctival hemorrhages on awakening may be another surrogate marker of otherwise unrecognized nocturnal convulsions.
The likely mechanism is an ictal Valsalva maneuver during the tonic phase of a generalized tonicclonic seizure resulting in capillary rupture.

\section{AUTHOR CONTRIBUTIONS}

Dr. Rigby: drafting/revising the manuscript. Dr. Sadler: drafting/revising the manuscript, study concept or design, study supervision.

\section{REFERENCES}

1. Reis JJ, Kaplan PW. Postictal hemifacial purpura. Seizure 1998;7:337-339.

2. Roth P, Zumsteg D. Seizure-induced periorbital petechial rash. Eur Neurol 2009;61:317. 


\section{Neurology}

\section{Teaching NeuroImages: Postictal subconjunctival hemorrhages and skin petechiae}

Heather Rigby and R. Mark Sadler

Neurology 2011;77;194

DOI 10.1212/WNL.0b013e3182242d80

\section{This information is current as of July 11, 2011}

Updated Information \& Services

References

Subspecialty Collections

Permissions \& Licensing

Reprints including high resolution figures, can be found at: http://n.neurology.org/content/77/2/194.full

This article cites 2 articles, 0 of which you can access for free at: http://n.neurology.org/content/77/2/194.full\#ref-list-1

This article, along with others on similar topics, appears in the following collection(s):

All Epilepsy/Seizures

http://n.neurology.org/cgi/collection/all_epilepsy_seizures

Clinical neurology examination

http://n.neurology.org/cgi/collection/clinical_neurology_examination Clinical neurology history

http://n.neurology.org/cgi/collection/clinical_neurology_history

Generalized seizures

http://n.neurology.org/cgi/collection/generalized_seizures

Information about reproducing this article in parts (figures,tables) or in its entirety can be found online at:

http://www.neurology.org/about/about_the_journal\#permissions

Information about ordering reprints can be found online:

http://n.neurology.org/subscribers/advertise

Neurology ${ }^{\circledR}$ is the official journal of the American Academy of Neurology. Published continuously since 1951, it is now a weekly with 48 issues per year. Copyright Copyright @ 2011 by AAN Enterprises, Inc.. All rights reserved. Print ISSN: 0028-3878. Online ISSN: 1526-632X.

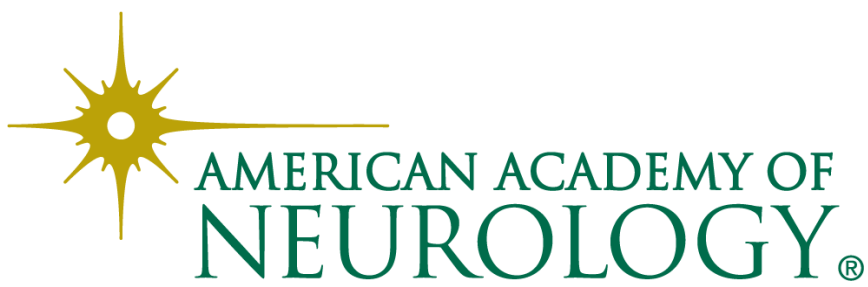

